REVIEW

\title{
Dynamic model of the short-term variability of microphytobenthic biomass on temperate intertidal mudflats
}

\author{
J.-M. Guarini ${ }^{1}$, G. F. Blanchard ${ }^{1,2, *}$, Ph. Gros $^{3}$, D. Gouleau ${ }^{1}$, C. Bacher ${ }^{1}$ \\ ${ }^{1}$ Centre de Recherche en Ecologie Marine et Aquaculture de L'Houmeau, UMR10 CNRS-IFREMER, BP 5, \\ 17137 L'Houmeau, France \\ ${ }^{2}$ Université de La Rochelle, Département de Biologie, Avenue Marillac, 17042 La Rochelle Cedex, France \\ ${ }^{3}$ IFREMER Centre de Brest, BP 70, 29280 Plouzané, France
}

\begin{abstract}
In the present paper, we list and document the relevant behavioral and physiological processes controlling primary productivity of epipelic microalgae on intertidal mudflats in order to develop a simplified model. We first propose, in an attempt to characterize the photosynthetically active biomass' of the epipelic community, a new approach to describe the photic environment at the sediment surface, by substituting a discrete 2 -layer model in place of continuous vertical light distribution. This concept thus allows us to build a functional representation of the distribution of the photosynthetically active biomass in the sediment and, by then integrating the light and temperature forcing of the latter biomass, to predict the dynamics of the whole epipelic community on short-term time scales. The model then clearly reveals an oscillatory behavior of the total biomass at the surface of the sediment, consistent with field biomass daily measurements performed during a spring-neap tidal cycle. Biomass increases occur during the diurnal emersion phase, in alternation with decreases during the submersion and nocturnal emersion phases; the dynamics of intertidal microphytobenthos is thus controlled by the night/day cycle and tidal hydrodynamic forcing, which determines the fast changes in environmental conditions (light and nutrient availability, temperature) which epipelic microalgae experience. The similarity between model simulations and field observations leads us to conclude that the conceptual framework of the model is valid.
\end{abstract}

KEY WORDS: Microphytobenthos - Intertidal mudflat - Primary production . Dynamic model . Migratory rhythm · Ecophysiological response

\section{INTRODUCTION}

Intertidal mudflats are among the most productive natural ecosystems in the world (Schelske \& Odum 1962). According to McLusky's (1989) classification of shallow embayments and estuaries, the absence of macrophytes provides a criterion for distinguishing between the 'European' and the 'American' typeswith much of the primary production being performed

·Corresponding author. E-mail: gerard.blanchard@univ-lr.fr by the microalgal assemblage growing on mud in the former. This community of microalgae is called the 'epipelon' in Round's (1971) terminology; in the following, the term 'microphytobenthos' will also be used interchangeably with 'epipelon'.

It is becoming increasingly obvious from recent investigations on the topic (Pinckney \& Zingmark 1991, 1993a, b, Blanchard \& Cariou-Le Gall 1994, Blanchard et al. 1996, Guarini et al. 1997, Vadeboncoeur \& Lodge 1998, Meyercordt \& Meyer-Reil 1999) that the major regulatory processes of intertidal microphytobenthic production act at spatio-temporal scales which greatly differ 
from the ones prevailing in the more widespread and documented pelagic systems of primary producers (Falkowski \& Woodhead 1992). However, despite this sudden awareness and some interesting attempts to explain how intertidal primary productivity proceeds (Brown et al. 1972, Pinckney \& Zingmark 1991), no theoretical scheme has yet been proposed to account for the full range of processes involved in this benthic system; there is obviously a lack of conceptual basis which hampers the appraisal of the role of intertidal microalgal productivity in the functioning of littoral ecosystems.

Therefore, it is our goal to list and document the relevant behavioral and physiological processes controlling primary productivity on intertidal mudflats, and to propose a simplified model which integrates those processes, provides an overview of intertidal epipelic primary productivity, and allows prediction of the shortterm temporal variations of microalgal biomass. The aim is clearly not to provide an exhaustive review of the subject, but rather to put together the relevant processes which allow a consistent conceptual framework to be worked out. We further propose a mathematical formulation of the resulting scheme, and its validation by comparing simulations with field observations.

We shall support our approach with the results we have obtained in Marennes-Oléron Bay (see references hereafter), located along the French Atlantic coast; microphytobenthos there has been shown to be the only primary producer on the intertidal mudflats (CariouLe Gall \& Blanchard 1995), which represent about $60 \%$ of the total surface area of the whole bay $\left(170 \mathrm{~km}^{2}\right)$. The meteorological conditions are typical of a temperate zone climate, with a strong seasonal variability, and the tidal range reaches $6 \mathrm{~m}$ during spring tides.

\section{PROCESSES CONTROLLING PRIMARY PRODUCTION}

Basically, we shall relate the control of primary production on intertidal mudflats to (1) the variations in position and concentration of epipelic microalgae biomass in surficial sediments, and (2) the combination of the seasonal, tidal, and nycthemeral cycles of external factors governing photosynthesis.

\section{The illuminated surface of the sediment and the photosynthetically active biomass layer}

Pelagic versus benthic photic zone: the vertical scales compression problem

Intertidal flats are characterized by very fine muds which considerably restrict the penetration of light into the sediment ${ }_{i}$ the $1 \%$ light level is indeed achieved at a depth of only a few hundred microns (Haardt \& Nielsen 1980, Colijn 1982, Jorgensen \& Des Marais 1986, Krause-Jensen \& Sand-Jensen 1998). As most of the benthic microalgal biomass occurs below this photic zone-high biomasses are usually found down to a depth of several centimeters due to mixing by physical and biological disturbances (Cadée \& Hegeman 1974, de Jonge \& Colijn 1994, Cariou-Le Gall \& Blanchard 1995) - only a small fraction contributes to primary production at a given time. Thus, with regard to productivity, the most fundamental issue is to characterize that fraction, the so-called 'photosynthetically active biomass' (PAB)

To sort this difficulty out, the usual approach-borrowed from the pelagic scheme-has been to compare the respective vertical distributions of light intensity, microalgal biomass and photosynthetic activity within the sediment (these profiles are assumed to be continuous). This has been made possible by recent technical advancements: scalar irradiance fiber-optic microprobes (Kühl \& Jorgensen 1992, Lassen et al. 1992) for light profiles, oxygen microelectrodes (Revsbech \& Jorgensen 1983, 1986) or fiber-optic oxygen microsensors (Klimant et al. 1995) for measurement of photosynthesis on vertical microscales, and the use of a pulse amplitude fluorometer which allows non-destructive tracing of microalgal biomass between surface and sub-surface (Serôdio et al. 1997, Hartig et al. 1998). Together, these profiles give new insight into the processes of primary productivity on microscales. However, measurement of microphytobenthic primary production is still a complicated task, hampered by severe methodological difficulties: first, some discrepancies between the results provided by the different technical devices call for further comparison studies (Revsbech et al. 1981, Wolfstein \& Hartig 1998); second, point measurements remain difficult to extrapolate.

However, we believe that the concept of light attenuation in intertidal muddy sediment is poorly suited for understanding the dynamics of microphytobenthic primary productivity: (1) In very fine muds the thickness of the photic zone is of the same order of magnitude as the length of the largest algal cells, and light attenuation can occur at the scale of a single cell. This contrasts sharply with the pelagic biotope, where the sizes of phytoplankton cells are several orders of magnitude less than the compensation depthi (2) microtopography is important, so that the sediment surface is not equally exposed to incident light; (3) the light attenuation coefficient in mud is strongly dependent on the organic matter and water contents, 2 features which are highly variable in time and space at different scales. 
It thus turns out that it is practically impossible to extrapolate such microscale measurements to mesoscale, the latter (several tens of $\mathrm{km}^{2}$ ) being the relevant spatial scale for addressing issues pertaining to the functioning of the ecosystem. Hence, in order to address this problem, we propose a simplified conceptual scheme; the steep physico-chemical vertical gradients are replaced by a discontinuity between a 2-layer environment. This approach may not be valid for sandy sediments where the light penetration and the microalgae distribution are different

\section{An alternative: the compartmental approach}

We therefore propose the following discrete representation of the photic microenvironment of epipelic algae, which first accounts for their most obvious property: their motility (for a review, see Harper 1977), and hence their ability to cope with the strong light attenu- ation in fine muds by moving towards the surface of the sediment. This amounts to consideration of a 'surface- or S-compartment' of microalgae receiving the full amount of incident sunlight

In support of this way of looking at the photic environment, i.e. substituting a discrete 2-layer model for a continuous vertical light distribution, the application of electron microscopy to the analysis of the surficial sediment microstructure (Gouleau 1976, Paterson \& Crawford 1986, Paterson 1989) has clearly shown that benthic microalgae concentrate on top of the sediment during diurnal low tides in the form of a continuous and uniform layer of cells (Fig. 1), which can be a 2-or 3-cell layer (Paterson 1986), under which there are only a few microalgae. Thus, such direct observations of the discontinuity in the biomass vertical distribution supports the idea of a 2-compartment conceptual model, the primary production of the microphytobenthic community occurring only in the surface microalgal compartment.
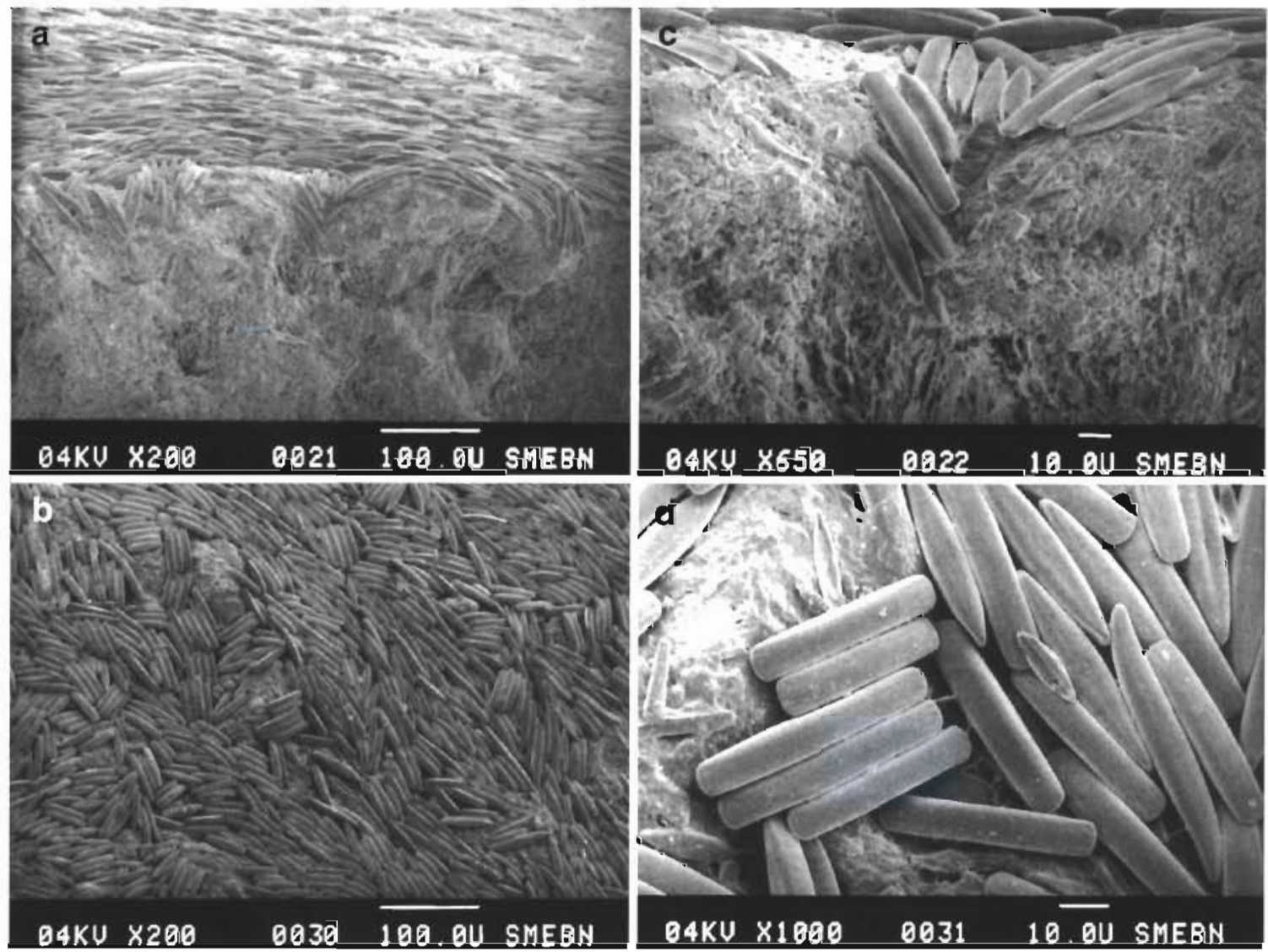

Fig. 1. Scanning Electron Microscopy for analysing the surficial sediment microstructure on intertidal mudflats and microalgal distribution. (a) Vertical profile of microalgal distribution. Microalgae (pennate diatoms) are concentrated on top of the sediment, thus constituting a 1- or 2-cell layer There are very few cells underneath in the photic zone of the sediment (the top first $100 \mu \mathrm{m}$ ). (b) Detail of the vertical profile showing the very thin biofilm of microalgae at the surface. (c) View of the surface of the sediment during low tide when covered with benthic microalgae. The biofilm is in the form of a continuous layer of cells at the surface. (d) Detail of the biofilm 


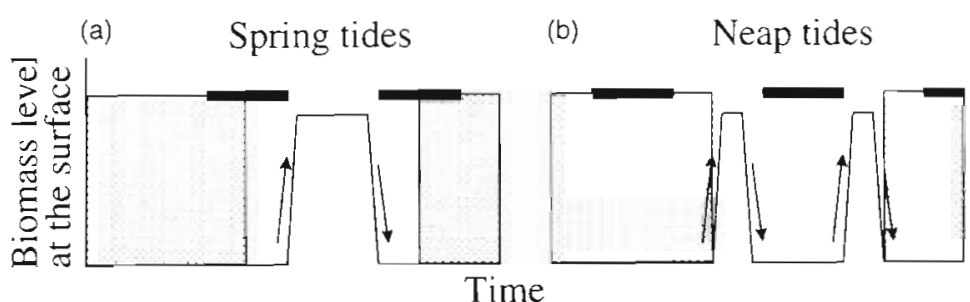

Fig. 2. Qualitative summary of the environmental synchronizers driving up and down the microphytobenthic biomass within the upper layer of the Marennes-Oléron intertidal mudflats. Shaded areas represent the night periods, and the horizontal thick bars represent high tide. Arrows indicate the direction of migration (this is a net movement of the whole community, all cell species being confounded) and the solid line represents the quantity of biomass at the surface of the sediment. The 2 extreme situations of phase shift between the semi-diurnal tide and the diurnal cycle are presented. (a) Low tide coincides with midday; there is only 1 complete diurnal emersion (a situation which occurs every spring tide in MarennesOléron Bay). (b) When high tide coincides with midday, there are 2 short diurnal emersions early in the morning and late in the afternoon. In such a case, a minimum of $1 \mathrm{~h}$ of exposure is necessary for migration to proceed in either the upward or downward direction

When considering biological processes, the filling up and emptying of the surface compartment (the biofilm) are the result of vertical migration (Aleem 1950, Callame \& Debyser 1954, Hopkins 1963, Palmer \& Round 1965, 1967, Round \& Palmer 1966, Round 1979 , Paterson 1986, Serôdio et al. 1997). Indeed, despite observed differences related to the behavior of individual species and discrepancies among authors about the tidal and/or diurnal nature of the rhythm, it is possible to emphasize the basic properties of the migratory behavior of microalgae (for a schematic representation, see Fig. 2). The rhythm is clearly endogenous (i.e. it persists under constant laboratory conditions) with apparently both a diurnal and a tidal entrainment: there is an upward movement of microalgae to the surface of the sediment a few minutes after the tide recedes only during the day, and a downward migra-

\section{a) Diurnal emersion}

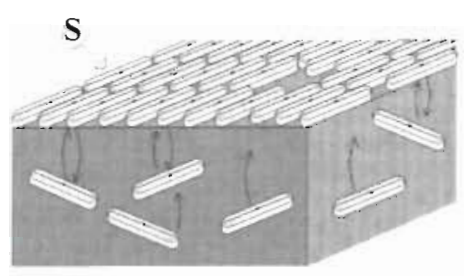

b) Submersion

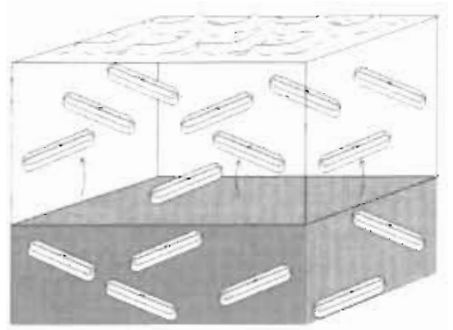

Fig. 3. Diagrammatic representation of the net migratory movement of epipelic microalgae. (a) During the diurnal emersion, the surface compartment $S$ is filled up with microalgae migrating from the aphotic compartment $B$; microalgae migrate downwards just prior to night emersion or submersion. (b) Microalgae can also be resuspended into the water column during submersion tion a few minutes before the incoming tide or at dusk when low tide straddles sunset. When they are at the sediment surface, microalgae constitute a biofilm (PAB) which remains quantitatively constant (Palmer \& Round 1967). Microalgae thus behave in a very predictable way, but the determinism of the rhythm (phototaxis, geotaxis, chemotaxis, thermotaxis, thigmotaxis) is not yet clearly understood.

First step of model building: mathematical formulation of between-compartment biomass fluxes for the two alternating states of the system

In light of such developments, we propose to schematize and formalize the dynamics of microphytobenthic biomass by means of a 2-compartment model (Fig. 3). (In all mathematical equations, state and forcing variables appear in plain text, while parameters and constants appear in italics.) Let us first consider a closed system (the source and sink terms will be introduced later). The upper S-compartment is completely filled with microalgae migrating from the lower aphotic B-compartment (the thickness of which is set at $1 \mathrm{~cm}$ ) at the beginning of diurnal emersion periods (Fig. 3a), and completely emptied at the end-by remigrating into the B-compartment-according to the vertical migration rhythm (Fig. 2). The following ordinary coupled differential equations thus describe the exchanges of biomass between the surface compartment $(\mathrm{S})$ and the aphotic compartment (B) during the diurnal emersion periods:

$$
\left\{\begin{array}{l}
\mathrm{dS} / \mathrm{dt}=r_{B} \mathrm{~B}\left(1-\mathrm{S} / S_{\max }\right) \\
\mathrm{dB} / \mathrm{dt}=-r_{B} \mathrm{~B}\left(1-\mathrm{S} / S_{\max }\right)
\end{array}\right.
$$

with $\mathrm{S}(\mathrm{t})$ and $\mathrm{B}(\mathrm{t})$ in $\mathrm{mg} \mathrm{chl} a \mathrm{~m}^{-2}$; the parameter $S_{\max }$ is the maximum biomass content of the surface biofilm when the sediment is completely covered by algal cells; sampling experiments in Marennes-Oléron Bay provided an estimate of $25 \mathrm{mg} \mathrm{chl} \mathrm{a} \mathrm{m}^{-2}$ for the $S_{\text {max }}$ value (Guarini 1998, Table 1); to obtain this value, we estimated the average number of diatoms (assuming it is Navicula) by counting cells at the surface of the sediment from a Scanning Electron Microscopy photograph. We found about $3.5 \times 10^{9}$ cells $\mathrm{m}^{-2}$; we then multiplied the density by the chl a content of the cells. $r_{B}$ is the net upward migration rate (Table 1), in time ${ }^{-1}$; this was deduced from measurements 
Table 1. Parameter values used in the simulations presented in Fig. 4; sources: Blanchard et al. (1997), Guarini (1998), Guarini et al. (1999). All parameters were assumed to be constant in space. Details on the computation of the forcing functions $E$ (Photosynthetically Available Radiation, PAR) and $\operatorname{I}_{M}\left(z_{0}, t\right)$ (Mud Surface Temperature, MST) are provided in Guarini et al. (1997)

\begin{tabular}{|c|c|c|}
\hline Parameter & Definition & Units \\
\hline \multicolumn{3}{|c|}{ Parameter values of the $P^{B}$ versus PAR and MST relationship } \\
\hline$E_{k}$ & Light saturation parameter & $100 \mathrm{~W} \mathrm{~m}^{-2}$ \\
\hline$P_{m}^{B}$ & Maximum photosynthetic capacity in April & $11.2 \mathrm{mgC}(\mathrm{mg} \mathrm{chl} \mathrm{a})^{-1} \mathrm{~h}^{-1}$ \\
\hline C:chla & Carbon to chlorophyll ratio & $45 \mathrm{~g} \mathrm{~g}^{-1}$ \\
\hline$T_{\max }$ & Maximum temperature for photosynthesis & $38^{\circ} \mathrm{C}$ \\
\hline$T_{\text {opt }}$ & Optimum temperature for photosynthesis & $25^{\circ} \mathrm{C}$ \\
\hline$\beta$ & Shape parameter & 2.0, dimensionless \\
\hline \multicolumn{3}{|c|}{ Parameter values of the slow-fast systems describing microphytobenthos local dynamics } \\
\hline$S_{\max }$ & Maximum biomass of the photosynthetic biofilm & $25 \mathrm{mg} \mathrm{chl} \mathrm{a} \mathrm{\textrm {m } ^ { - 2 }}$ \\
\hline$r_{S}=r_{B}$ & Net exchange rate of biomass between compartments $\mathrm{S}$ and $\mathrm{B}$ & $1.0 \mathrm{~h}^{-1}$ \\
\hline$m_{S}=m_{B}$ & Net loss rate of biomass during diurnal emersion & $0.040 \mathrm{~h}^{-1}$ \\
\hline$\mu_{S}=\mu_{B}$ & Idem, during night emersion or submersion & $0.065 \mathrm{~h}^{-1}$ \\
\hline
\end{tabular}

of the migration speed of the benthic diatoms. The value that we used is an average value of those reported by Hay et al. (1993), who measured the migration speed of different species of benthic diatoms in different environmental conditions. It is worth emphasizing the density-dependence of epipelic primary production accounted for by $1-\left(\mathrm{S} / S_{\max }\right)$; this term represents the feedback due to space limitation in the surface 'niche', and hence due to the competition for light in the microalgal community. Its functional role shares some analogy with the self-shading regulatory process of phytoplanktonic production.

Just prior to submersion and night emersion periods, microalgae migrate downwards from compartment $\mathrm{S}$ to $\mathrm{B}$ (the biofilm disappears); the system is then described by a second set of differential equations:

$$
\left\{\begin{array}{l}
\mathrm{d} S / \mathrm{dt}=-r_{S} \mathrm{~S} \\
\mathrm{~dB} / \mathrm{dt}=r_{S} \mathrm{~S}
\end{array}\right.
$$

Here $r_{S}\left(\right.$ time $\left.^{-1}\right)$ denotes the net downward migration rate (Table 1), and is considered as being equal to the upward migration rate (there is no experimental evidence against such an assumption).

\section{Light and temperature forcing of the photosynthetic capacity $\left(P^{B}\right)$ of PAB}

Relationship between microphytobenthic community photosynthetic rate and light

Microphytobenthic communities generally do not exhibit photoinhibition (Burkholder et al. 1965, Gargas 1971, Rasmussen et al. 1983). Blanchard \& Cariou-
Le Gall (1994) have nevertheless shown that microalgae, isolated from the sediment and experimentally maintained at high light levels for $3 \mathrm{~h}$, exhibit photoinhibition. As the same microalgal community does not experience photoinhibition in situ after a longer exposure period, and because photoinhibition is a timedependent process (Neale 1987), they suggested that microalgae avoid inhibitory conditions by moving downwards within the sediment during exposure periods when sunlight is too bright: this tiny vertical adjustment thus prevents microalgae from photoinhibiting while still photosynthesizing at their highest rate. This mechanism has been demonstrated recently by Kingston (1999) on euglenoids in sandy sediments.

In the absence of photoinhibition, Jassby \& Platt's (1976) equation has been shown to provide the best fit to experimental data:

$$
P^{B}(\mathrm{E})=P_{m}^{B} \times \tanh \left(\mathrm{E} / E_{k}\right)
$$

According to the terminology of Sakshaug et al. (1997), $P^{B}(\mathrm{E})$ is the photosynthetic rate (mg C $[\mathrm{mg}$ chl a $\left.]^{-1} \mathrm{~h}^{-1}\right)$ at light level $\mathrm{E}\left(\mu \mathrm{mol} \mathrm{m} \mathrm{m}^{-2} \mathrm{~s}^{-1}\right) . E_{k}$ is the light saturation constant ( $\mu \mathrm{mol} \mathrm{m} \mathrm{m}^{-2} \mathrm{~s}^{-1}$ ); 5 experiments were performed between April 1996 and January 1997 in Marennes-Oléron Bay (measurements using a photosynthetron, Lewis \& Smith 1983), which yielded statistically identical $E_{k}$ estimates; the value of $460 \mu \mathrm{mol} \mathrm{m} \mathrm{m}^{-2}$ $\mathrm{s}^{-1}\left(100 \mathrm{~W} \mathrm{~m}^{-2}\right)$ will thus be used hereafter. In contrast, the parameter $P_{m}^{B}$ (the maximal photosynthetic rate normalised to chl $a$, expressed in $\mathrm{mg} \mathrm{C}$ [ $\mathrm{mg} \mathrm{chl} a]^{-1} \mathrm{~h}^{-1}$ ) exhibits variations at time scales similar to the ones of mud surface temperature (Blanchard et al. 1996, 1997; see below). 
Modelling the dependence of $P^{B}$ upon seasonal and hourly temperature variations

During diurnal emersion periods, when microalgae are at the surface of the mud (PAB in compartment S), the mud surface temperature (MST) exhibits large $\left(>10^{\circ} \mathrm{C}\right.$ ) and rapid $\left(\mathrm{ca} 3^{\circ} \mathrm{C} \mathrm{h}^{-1}\right)$ changes (Harrison 1985, Harrison \& Phizacklea 1987). PAB thus undergoes the same variations, which strongly influences photosynthetic activity; Blanchard \& Guarini (1996) have shown indeed that MST forces the photosynthetic capacity $\left(P^{B}\right)$, especially during low tide.

Therefore, Guarini et al. (1997) modelled the dynamics of MST of intertidal flats in order to investigate the spatio-temporal fluctuations of the photosynthetic capacity. Basically, the temporal evolution of mud temperature at depth $\mathrm{z}$ and time $\mathrm{t}, \mathrm{T}_{\mathrm{M}}(\mathrm{z}, \mathrm{t})$, is governed by the first law of thermodynamics with isobaric transformation:

$$
\rho_{M} C_{P M} \frac{\partial \mathrm{T}_{M}(\mathrm{z}, \mathrm{t})}{\partial \mathrm{t}}=\frac{\partial}{\partial \mathrm{z}}\left(\lambda_{M} \frac{\partial \mathrm{T}_{M}(\mathrm{z}, \mathrm{t})}{\partial \mathrm{z}}\right)
$$

where $\rho_{M}$ is the mass of mud per unit of volume $\left(\mathrm{kg} \mathrm{m}^{-3}\right) ; C_{P M}$ is the specific heat capacity of mud at constant pressure $\left(\mathrm{J} \mathrm{kg}^{-1} \mathrm{~K}^{-1}\right)$; and $\lambda_{M}$ is the conductivity $\left(\mathrm{W} \mathrm{m} \mathrm{m}^{-1} \mathrm{~K}^{-1}\right) . \mathrm{T}_{\mathrm{M}}(\mathrm{z}, \mathrm{t})$ is the instantaneous vertical profile of mud temperature $(\mathrm{K})$, whose variations are forced by the alternating boundary condition at the mud surface (i.e. at $z=z_{0}$ ):

$$
\begin{aligned}
& \left.\lambda_{M} \frac{\partial \mathrm{T}_{\mathrm{M}}(\mathrm{z}, \mathrm{t})}{\partial \mathrm{z}}\right|_{\mathrm{z}=z_{\mathrm{Q}}} \\
& \quad=\left\{\begin{array}{l}
R_{S}+R_{\text {Atm }}-R_{M}-S_{M u d \rightarrow \text { Air }}-V_{M} \text { during emersion } \\
S_{\text {Mud } \rightarrow \text { Water }}
\end{array}\right.
\end{aligned}
$$

The right-hand terms are the components of the Heat Energy Balance, i.e. the fluxes $\left(\mathrm{W} \mathrm{\textrm {m } ^ { - 2 }}\right)$ of radiation coming from the sun $\left(R_{S}\right)$, from the atmosphere ( $R_{\text {Atm }}$ infrared radiation), from the receiving surface $\left(R_{M}\right)$, the sensible heat fluxes by conduction due to the temperature differences between mud and air $\left(S_{M u d \rightarrow A_{i r}}\right)$ or between mud and water $\left(S_{M u d \rightarrow \text { Water }}\right)$, and the flux of evaporation $\left(V_{M}\right)$ depending on the mud water content. Spatialization of the local equation is thus provided by an hydrodynamic model which calculates the total water height variations over the intertidal area (Le Hir et al. 1993). A detailed presentation of parameterization and validation of the MST model has been given by Guarini et al. (1997).

The coupling between MST and $P^{B}{ }_{m}$ dynamics is then made possible by means of the following equation, whose parameters have been experimentally determined at the same temporal scale of variation as that of MST (Blanchard et al. 1996, 1997): where $\mathrm{T}_{\mathrm{M}}\left(z_{0}, \mathrm{t}\right)$ denotes the computed $\mathrm{MST}_{i} P_{m}^{S}$ (mg C $\mathrm{mg}^{-1} \mathrm{chl} \mathrm{a} \mathrm{\textrm {h } ^ { - 1 }}$ ) is the maximum value of $P^{B}{ }_{m}(\mathrm{~T})$ at the optimum temperature, $T_{\text {opt }}\left({ }^{\circ} \mathrm{C}\right) ; T_{\max }\left({ }^{\circ} \mathrm{C}\right)$ is the lethal temperature at which $P_{m}^{B}(T)$ decreases to $0 ; \beta$ is a dimensionless shape parameter. Blanchard et al. (1.997) have shown that the values of the parameters $T_{\text {opt }}, T_{\text {max }}$ and $\beta$ remain constant the whole year round, respectively $25^{\circ} \mathrm{C}, 38^{\circ} \mathrm{C}$, and 2 ; on the other hand, the superscript ${ }^{S}$ of the fourth parameter $P^{S}$ indicates the seasonal variability of the maximum value of the photosynthetic capacity. The model therefore allows both short- (alternating emersion/submersion periods), medium- (lunar cycles) and long-term (between seasons) MST variations to be taken into account.

In addition, the existence of an endogenous rhythm of the photosynthetic activity of epipelic algae has been demonstrated by Brown et al. (1972): when isolated from the sediment and maintained in the laboratory under constant light and temperature conditions, microalgae exhibit temporal changes of their photosynthetic activity in accordance with a tidal rhythm superimposed on a diurnal rhythm. The authors further concluded that this rhythmicity was in phase with that of the vertical migration. It is likely that the variation of the mud surface temperature entrains this endogenous rhythm because it exhibits a similar rhythmicity.

Potentially photosynthetically active biomass (PPAB) in the B-compartment

According to our model, intertidal benthic primary production is solely due to the photosynthetic activity of the biofilm of microalgae which covers the surface of the sediment: production is performed by PAB in compartment $S$, i.e. by a small fraction of the total biomass 'diluted' in the top first centimeters. But what is then the photosynthetic potential of the biomass in the underlying aphotic sediment referred to as compartment B?

Blanchard \& Cariou-Le Gall (1994) have shown on an intertidal mudflat that the photosynthetic capacity-i.e. the photosynthetic rate at light saturation under nutrient sufficiency and at constant temperature - was the same at a depth of $5 \mathrm{~mm}$, a completely aphotic environment, as at the surface; they concluded that the homogeneity of the photosynthetic response was due to the mixing of at least the top $5 \mathrm{~mm}$ of the sediment by physical and/or biological processes. In a subtidal environment, Macintyre \& Cullen (1995) found similar results; they observed a physically mixed layer in the underlying 8 to $15 \mathrm{~mm}$. Wasmund (1989) showed that microalgae from the aphotic zone of the

$$
\left\{\begin{array}{l}
\mathrm{T}_{\mathrm{M}}\left(z_{0}, \mathrm{t}\right)<T_{\text {max }}: P_{m}^{B}\left[\mathrm{~T}_{M}\left(z_{0}, \mathrm{t}\right)\right]=P_{m}^{S}\left(\frac{T_{\max }-\mathrm{T}_{\mathrm{M}}\left(z_{0}, t\right)}{T_{\max }-T_{\text {opt }}}\right)^{\beta} \exp \left[-\beta\left(\frac{T_{\text {max }}-\mathrm{T}_{\mathrm{M}}\left(z_{0}, \mathrm{t}\right)}{T_{\max }-T_{\text {opt }}}-1\right)\right] \\
\mathrm{T}_{\mathrm{M}}\left(z_{0}, \mathrm{t}\right) \geq T_{\max }: P_{m}^{B}\left[\mathrm{~T}_{\mathrm{M}}\left(z_{0}, \mathrm{t}\right)\right]=0
\end{array}\right.
$$


sediment (down to a depth of about 2 to $3 \mathrm{~cm}$ ) were alive, retained their photosynthetic capability and immediately resumed their photosynthetic activity when exposed to light. Although intertidal microphytobenthos migrates vertically, this process is not likely to be entirely responsible for the observed similarity of the photosynthetic potential between the photic and aphotic layers; Hay et al. (1993) indeed measured the migration speed of diatoms and they concluded that benthic diatoms do not move more than 2 to 3 mm during the course of an emersion or submersion period. Therefore, vertical migration cannot completely explain the presence of potentially photosynthetically active cells at a depth of $1 \mathrm{~cm}$.

We infer therefore from these different observations that the epipelic biomass in the first centimeter of the sediment (i.e. compartment $B$, the thickness of which is the usual reference for measuring the biomass; see Colijn \& de Jonge 1984) exhibits the same physiological characteristics (particularly the same $P_{m}^{B}$ ) as the PAB. We thus define the content of the B-compartment as the PPAB. Therefore, the only difference between PAB and PPAB is that the former actually photosynthesizes because of light availability, whereas the latter does not.

As a result, any exchange of cells between both compartments $\mathrm{S}$ and $\mathrm{B}$ during the emersion periods will not affect their photosynthetic characteristics: this is a necessary condition for the consistency of our model (see below). Cells retain their photosynthetic capability while in compartment B during submersions and night emersions, and immediately resume their activity when they migrate back to compartment $\mathrm{S}$.

\section{MODEL OF BENTHIC INTERTIDAL PRIMARY PRODUCTION}

\section{Model equations and parameters}

\section{Second step of model building: definition of sources and sinks of biomass}

Let us now consider an open system model, including the vertical migration scheme previously described, and also the gain/loss processes; light and temperature forcings at the surface of the sediment are provided by the thermodynamic model summarized above. We now describe the dynamics of interacting compartments $S$ and $B$ during diurnal emersion periods as

$$
\left\{\begin{array}{l}
\frac{\mathrm{d} \mathrm{S}}{\mathrm{dt}}=\left(r_{B} \mathrm{~B}+p^{B} \mathrm{~S}\right)\left(1-\mathrm{S} / S_{\max }\right)-m_{S} \mathrm{~S} \\
\frac{\mathrm{dB}}{\mathrm{dt}}=-r_{B} \mathrm{~B}\left(1-\mathrm{S} / S_{\max }\right)+p^{B} \mathrm{~S} \frac{\mathrm{S}}{S_{\max }}-m_{B} \mathrm{~B}
\end{array}\right.
$$

Besides the previously defined parameters, $r_{B}$ and $S_{\text {max }}$, we introduce $p^{B}$, the production rate of $S$; therefore, the product $p^{B} \mathrm{~S}$ is the source term of new biomass. $p^{\mathrm{B}}$ is simply $P^{B}$ converted by using an estimated C:chl a ratio of 45 (Guarini 1998); this constant value was retained because of the lack of complementary measurements allowing us to quantify the likely variability of the C:chl a ratio. We thus emphasize that the shorthand notation $p^{B}$ stands for $p^{B}\left[\mathrm{E}, \mathrm{T}_{\mathrm{M}}\left(z_{0}, \mathrm{t}\right)\right]$, where:

$p^{B}\left[\mathrm{E}_{1} \mathrm{~T}_{\mathrm{M}}\left(z_{0}, \mathrm{t}\right)\right]=(\mathrm{C}: \mathrm{chl} \mathrm{a}) \times P_{m}^{B}\left[\mathrm{~T}_{\mathrm{M}}\left(z_{0}, \mathrm{t}\right)\right] \times \tanh \left(\mathrm{E} / E_{k}\right)$

This latter formula highlighting explicitly how PAR and MST 'forces' the modelled system; $m_{S}$ and $m_{B}$ are the net biomass loss rates (time ${ }^{-1}$ ) in $\mathrm{S}$ - and B-compartments, respectively (i.e. their products with the state variables give the sink terms). Since these loss processes are poorly known, they are considered as linear functions of microphytobenthic biomass of each compartment. The term $p^{B} \mathrm{~S}\left(\mathrm{~S} / S_{\max }\right)$ in compartment $\mathrm{B}$ is not a production term sensu stricto, but a transfer term: it is equal to instantaneous production when $\mathrm{S}=$ $S_{\text {max }}$ and it is equal to 0 when compartment $S$ is empty $(S=0)$.

During submersion and night emersion periods, the dynamics is:

$$
\left\{\begin{array}{l}
\frac{\mathrm{dS}}{\mathrm{dt}}=-r_{S} \mathrm{~S}-\mu_{S} \mathrm{~S} \\
\frac{\mathrm{dB}}{\mathrm{dt}}=r_{S} \mathrm{~S}-\mu_{B} \mathrm{~B}
\end{array}\right.
$$

where $\mu_{S}$ and $\mu_{B}$ are the net global loss rates (time ${ }^{-1}$ ) of biomass $S$ and $B$, respectively. It is worth emphasizing the composite significance of these $\mu$ rates, which encompass distinct underlying processes: biological ones (natural mortality, grazing by meio- and macrofauna), and also physical ones (net losses in the balance of sedimentation/resuspension of microalgae). More generally, the parcimonious formulation of the sinks of sedimentary chl a biomass (relying upon first-order decay at constant $m$ or $\mu$ rates) is a consequence of the lack of knowledge which would have been necessary for the definition of a more detailed model

The values of the parameters are given in Table 1; in accordance with the gaps just mentioned, we have made the symplifying assumption $m_{S}=m_{B}=m$ and $\mu_{S}=\mu_{B}=\mu$. Furthermore, a first-order sensitivity analysis has been performed (Guarini et al. 1999), which revealed the model sensitivity to the $S_{\max }$ biomass value and to the photosynthetic rate, and to a much lesser extent to the poorly known $m$ and $\mu$ parameters. 
Dynamical behaviour of the system/ practical consequences for model validation

In our model, the dynamics of intertidal microphytobenthos is thus mainly controlled by the hydrodynamic forcing, which determines the sequence of the 2 alternate environmental states (diurnal emersion, submersion or night emersion). Guarini (1998) and Guarini et al. (1999) have analysed the mathematical properties of the 2 associated slow-fast systems, and have shown that the whole model solutions rapidly converge towards a stable cyclic equilibrium (see phase portrait, Fig 4). Basically, they pointed out that the net migration rates $r$ are 1 or 2 orders of magnitude greater than

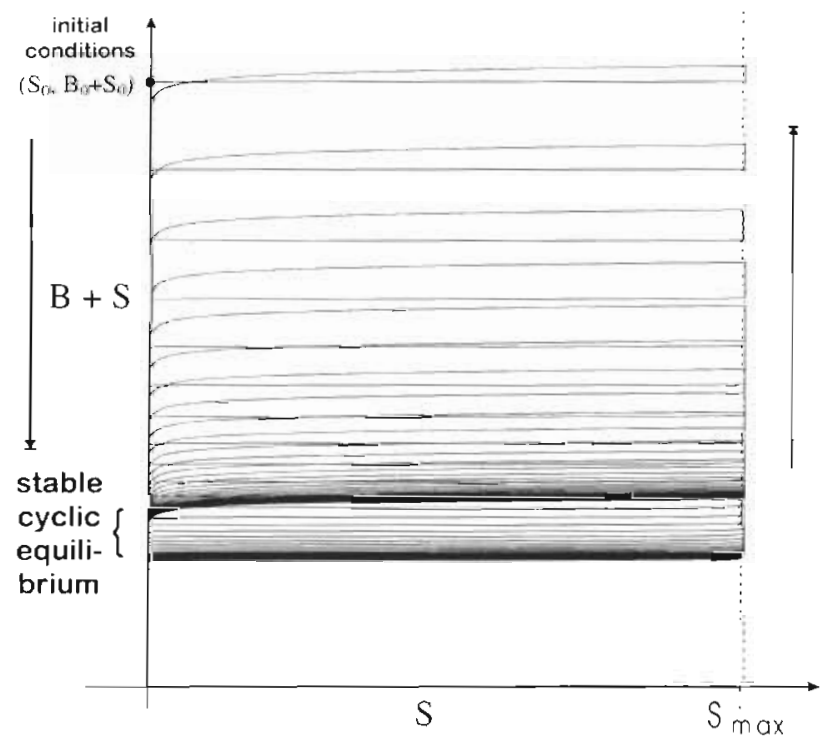

Fig. 4. Phase diagram showing microphytobenthic biomass trajectory in the $(S, B+S)$ plane, i.e. simultaneous change of total biomass $B+S$ in the topmost $\mathrm{cm}$ of the mud versus biomass in the S-compartment. Starting from arbitrary initial conditions $\left\{S_{0} \geq 0, B_{0} \geq 0\right\}$, with $B_{0} \geq S_{\max }$, the system rapidly converges to a stable cyclic equilibrium. Therefore, a qualitative assessment of the validity of the model must rely upon a sampling scheme aiming at cherking (1) the global stationarity of chl a biomass at the time scale of ca $2 \mathrm{wk}$, and (2) the existence of higher frequency (daily) oscillations around the stable trend. According to the mathematical properties of this slow-fast system, it is then necessary to sample the sedimentary chl a biomass at the end of each slow phase, i.e. at the beginning and at the end of each complete diurnal emersion period. Otherwise, one could erroneously infer short-term biomass stability by observing the system at midpoints of each slow phase (roughly speaking, the slow phase corresponds here to the sections of biomass trajectory along the vertical axes $\mathbf{S}=0$ and $S=S_{\text {maxi }} S$ is the fast variable). The vertical arrows indicate the direction of biomass trajectories during the slow phase the photosynthetic production rate $p^{B}$, the latter being itself 1 order of magnitude greater than the net biomass loss rates $m$ and $\mu$. It is therefore possible to define a 'slow variable', $\mathrm{B}+\mathrm{S}$ (Fig. 4, ordinate), which depends only on the lowest rates $m, \mu$, and $p^{B}$, and a 'fast variable', $\mathrm{S}$ (Fig. 4, abscissa), whose dynamics is mainly controlled by the highest rates $r$. The decoupling of time scales then allows analytical stepwise time integrations.

In a more descriptive way, an active upwards migration quickly transfers biomass from $\mathrm{B}$ to $\mathrm{S}$ at the beginning of the diurnal emersion period, until the maximum S-biomass $S_{\max }$ of the biofilm is reached; this results in a quasi-instantaneous decrease of $\mathrm{B}$. Then the photosynthetically produced biomass in $\mathrm{S}$ during diurnal emersion is continuously transferred to $B$, which results in a slow increase of $B$. At the beginning of submersion periods, the S-biomass is entirely and rapidly transferred to $B$ (the biofilm $S$ is quasi-instantaneously emptied); this results in a sudden increase of bionass in $\mathrm{B}$, which decreases slowly thereafter during submersion due to biological (grazing, physiological mortality) and physical (resuspension) loss processes.

Let $D$ be the diurnal emersion period, and $N$ be night emersion and submersion periods; furthermore, let $T_{D}$ and $T_{N}$ be the respective durations of the $D$ and $N$ periods. For the sake of clarity, Fig. 4 illustrates the elementary theoretical case where $T_{D}=T_{N}$ (i.e. nycthemeral and semi-diurnal tidal cycles opposite in phases), with $p^{8}=$ constant. It is then straightforward to derive an analytical formulation of the amplitude of biomass oscillations at equilibrium. A slightly more complicated result is obtained for the realistic case where $p^{B}$ is light and temperature dependent, and thus time varying, and where there is a continuous phase shift between nycthemeral and tidal cycles, i.e. when $T_{D}$ and $T_{N}$ vary according to a spring/neap tidal cycle of $14.6 \mathrm{~d}$. In this latter case, we have also shown that the system exhibits a stable cyclic equilibrium (see Guarini et al. 1999).

From a sampling strategy standpoint, these dynamic properties of the system imply that the series of oscillations (short-term dynamics) can be pointed out only by observing the microphytobenthic community at the end of each slow phase to detect the lowest and highest value of the biomass (see Fig. 4). This practically amounts to measuring epipelic biomass at the beginning and at the end of each diurnal emersion period (see Fig. 5 below, left-hand panels). In contrast, if biomass was sampled at low tide slack-as is often the case in studies pertaining to intertidal epipelonone would get an intermediate value of biomass, stable from day to day, thus giving the false impression that epipelic biomass does not change on short-term time scales. 
OBSERVED Chl $a$ EPIPELIC BIOMASS
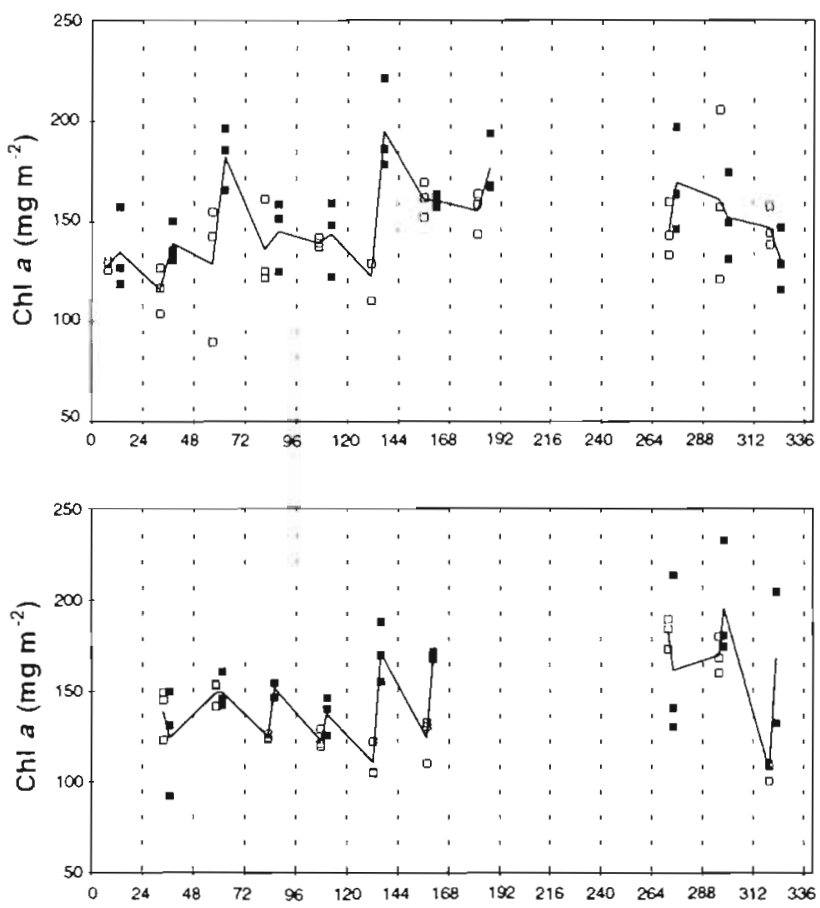

SIMULATED Chl $a$ BIOMASS

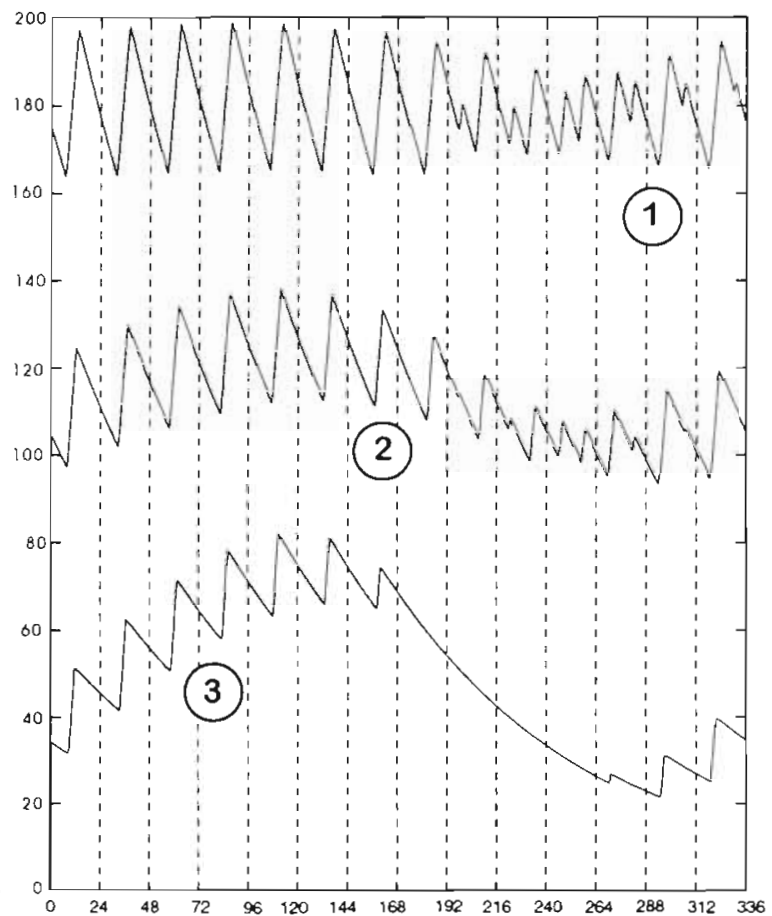

Abscissa scales: time in hours, from 7 to 20 April 1997

Fig. 5. Comparison of field data (left-hand panels: $\square$, chl a concentration at the beginning of emersion periods; $\mathbf{m}$, chl a concentration at the end of emersion periods) with model results (right-hand panel): observed versus simulated time series of microphytobenthic biomass ( $\mathrm{chl} \mathrm{a,} \mathrm{mg} \mathrm{m}^{-2}$ ) during a spring-neap tide cycle of $14.6 \mathrm{~d}$ (abscissa scale in hours, with $24 \mathrm{~h}$ time intervals indicated by vertical dotted lines). Results shown here are typical of the environmental (temperature, photoperiod) and 'physiological' (maximum photosynthetic capacity value) conditions prevailing in April in Marennes-Oléon Bay. Left-hand panels: results of the microphytobenthic biomass measurements performed in the topmost centimeter of the sediment. The 2 sampling sites are located near the middle topographic level of the mudflat; their average emersion durations are 6 (top left) and 4 (bottom left) h per tidal semi-diurnal cyle respectively. Triplicate in situ biomass samples were collected at low tide, at the beginning ( $(a)$ and at the end ( $)$ of each complete diurnal emersion period; average biomasses per triplicate are joined by the solid lines. The missing values (no sampling) in the time-series correspond to neap tides, when emersion occurs only partially during

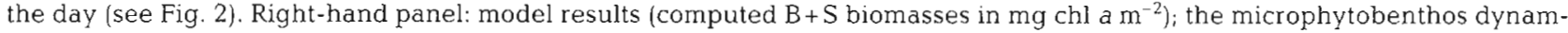
ics are simulated at 3 topographic levels of the mudflat. The upper 2 curves show the temporal evolution of $\mathrm{B}+\mathrm{S}$ in the upper reaches of the flat (Curve 1), and also at intermediate topographic levels (Curve 2). In order to compare with field data, notice that the topographic levels of the 2 sampling sites define a narrower range within the one corresponding to Curves 1 and 2 . Curve 3 describes biomass variations in the lower area of the flat, which remains submerged during neap tides; accordingly, B+S decreases regularly over about $6 \mathrm{~d}$. All 3 curves display the dynamic equilibrium of the system (cf. Fig. 4) after decay of transients

\section{Model results and comparison with field data}

Simulations of microphytobenthic biomass during a spring-neap tide cycle (here, in the case of semi-diurnal tide occurring in April in Marennes-Oléron Bay along the French Atlantic coast) at different bathymetric levels of the mudflat (i.e. different emersion durations) are presented in Fig. 5. Apart from the fact that the bathymetric level has an obvious influence on the simulated biomass, the most striking feature is the oscillatory behavior of the biomass dynamics around a globally stable average biomass value at a $2 \mathrm{wk}$ time scale. These oscillations depict the successive increases of biomass during diurnal emersions and de- creases during the other periods. The amplitude of variation is highest during spring tides and diminishes towards neap tides because of shorter emersion periods; actually, there are 2 diurnal emersions during neap tides, and hence 2 smaller daily oscillations (clearly apparent on Curves 1 and 2, right-hand panel Fig. 5). Besides, the average biomass is relatively stable at high levels on the mudflat, whereas it tends to increase during spring tides and to decrease during neap tides at mid-levels. The latter spring-neap tide trend is more pronounced at the lowest levels on the mudflat (see Curve 3, right-hand panel Fig. 5); indeed, the decrease in average biomass during neap tide is particularly sharp because the water column turbidity 
prevents light from attaining the sediment surface for several days.

To attempt to validate the model, Blanchard et al. (1998) performed a field study which aimed at testing the main prediction of the oscillatory dynamics of the biomass. They measured epipelic biomass at the beginning and at the end of each complete diumal emersion period over $14 \mathrm{~d}$ (a lunar cycle in April) at 2 sites in the mid-level of a mudflat: despite both technical difficulties in sampling and local variability due to patchiness, they did observe a series of oscillations of the same amplitude as the one computed in the simulations (ca $15 \%$ of the biomass in the first $\mathrm{cm}$ of the sediment, see Fig. 5, left-hand panels). Furthermore, they have shown that these short-term oscillations are statistically significant. Therefore, because of the occurrence of these 2 fundamental predicted features, they concluded that the conceptual frame of the model was valid.

Other simulations (not shown here) have been performed under different environmental conditions, taking the seasonal variability of $P_{m}^{S}$ into account. In particular, the model reproduces the microphytobenthic biomass summer depletion (see Guarini 1998). In every case, however, simulated biomasses exhibit a spatial structure governed by the topography of the mudflat, a feature which has not been observed when sampling epipelic chl a over the $110 \mathrm{~km}^{2}$ of the whole MarennesOléron Bay intertidal area (Guarini et al. 1998). This discrepancy, partly attributable to the assumed constancy of the biomass loss rate terms (an obviously oversimplifying assumption), is discussed hereafter.

\section{Towards further improvements in biomass control modelling}

A more realistic formulation of nutrient limitation?

The model that we propose is based on the assumption that nutrient limitation is not a 'dominant' regulatory process; however, because a dense biofilm (i.e. compartment S) forms at the surface during diurnal emersions, the nutrient pool in the topmost layer of the sediment interface can be exhausted very quickly, and hence the diffusion rate of nutrients from below might be limiting (Admiraal 1984). If this occurs, the implicit hypothesis concerning nutrient availability in our model turns out to be somewhat contradictory with the production scheme, i.e. coupled nutrient uptake and production in compartment $\mathrm{S}$ during diurnal emersion periods.

Therefore, we cannot directly link production to the immediate nutrient availability in the surrounding medium; it would be rather more appropriate to account for an uncoupling of nutrient uptake and carbohydrate production. So, we could thus define a production system which is not dependent upon the external nutrient concentration-globally abundant, but locally unavailable - but upon an intracellular compartment (i.e. reserves). This would imply the introduction into the model of 2 new state variables $\left(Q_{S}\right.$ and $Q_{B}$ ) representing the intracellular nutrient pools in $S$ and $B$, respectively, for instance according to Droop's (1974) formulation. Nutrient assimilation occurs in compartment $B$ during submersion and emersion periods; nutrients are metabolized in compartment $\mathrm{S}$ during emersions only. Tentative simulations (not shown here) have been realized with intracellular quota values gathered from the literature (Guarini 1998). When compared with previous results, the main change is a strong attenuation of the dependence of biomass spatial structures upon the mudflat topography, and the disappearance of the model tendency to overestimate biomasses in the higher levels of the intertidal zone.

\section{Coupling with physical processes at the mud-water interface}

This topic has not been explored in the present article; it is nevertheless a very promising area of progress in the understanding of the ecological role of microphytobenthos in coastal food webs. The observed time series presented on Fig. 5 show that, despite high productivity, epipelic biomass remains approximately stationary at the $2 \mathrm{wk}$ time scale. With the exception of natural mortality and local grazing, the most likely explanation lies with the resuspension and transport processes; it is possible to account for the latter with an advection/dispersion model. However, the former processes, acting in the boundary layer, are not yet fully understood and require further investigations.

\section{CONCLUSION}

The aim of this work was to build a coherent representation of the intertidal microalgal primary production system by integrating the present knowledge available in recent literature. This knowledge has however accumulated at a slow rate so that it is far behind the state-of-the-art in the understanding of pelagic primary production processes. Numerous technical reasons may account to some extent for this relatively slower development: sampling (or in situ studying) of benthos is indeed much more time consuming and problematic than sampling of plankton. As a matter of fact, there are far fewer benthic models, and those that exist contain 'black boxes' 
which reveal the need for comprehensive results about many topics.

In this respect, we propose some new guidelines for the elaboration of a modelling strategy of microphytobenthic production, particularly in the intertidal areas. We emphasize that our approach does not rely upon an adaptation of the concepts and methods suited for pelagic primary production modelling, but on new concepts. Indeed, epipelic intertidal microalgae permanently undergo fast changes from an air-sediment interface to a water-sediment interface, and vice versa; thus, the physical forcings on microphytobenthic productivity do not operate at the same time scales as in the pelagic biotope. Furthermore, abiotic factors act in conjunction with active displacements of epipelic microalgae: for instance, the biomass increase during emersion periods is, firstly, due to the migration of microalgae at the surface of the sediment to form a dense biofilm and, secondly, due to the hourly light and temperature forcings of the photosynthetic capacity of this biofilm

We have thus pointed out 3 basic features of the microphytobenthic production system: (1) benthic microalgae exhibit a migratory behavior towards light, (2) the light micro-environment at the surface of the sediment may be likened to a discrete 2 -compartment model (the surface compartment being saturated with biomass), and (3) because of its high frequency-high amplitude variations in mud, temperature is a prominent factor in controlling the dynamics of benthic primary production.

Finally, we consider this model as a basis for describing the dynamics of intertidal microphytobenthos; it undoubtedly contributes to lessening the gap which separates the level of conceptualization of benthic systems, on the one hand, and pelagic systems, on the other hand. However, it clearly calls for further developments: experimental work needs to be conducted in order to elucidate the use of the nutrient pool by epipelic microalgae, and to explore the possibility of a nutrient limitation. But also, the global loss rates of our model have to be split into grazing and resuspension (formulation of this latter process depends upon processes of sedimentary dynamics at the mud-water interface), particularly with the perspective of assessing the role of microphytobenthos in the matter budget of a coastal ecosystem.

Acknowledgements. This study was supported by the Région Poitou-Charentes and by the European Community (MAST 3, CT95-0022 INTRMUD Project), associated with the Centre National de la Recherche Scientifique (CNRS) and the Institut Français de Recherche et d'Exploitation de la Mer (IFREMER). We also thank the anonymous referees for their useful comments.

\section{LITERATURE CITED}

Admiraal W (1984) The ecology of estuarine sediment-inhabiting diatoms. In: Round FE, Chapman DJ (eds) Progress in phycological research, Vol 3. Biopress Ltd, Bristol, p 269-322

Aleem AA (1950) The diatom community inhabiting the mudflats at whitstable. New Phytol 47:174-188

Blanchard GF, Cariou-Le Gall V (1994) Photosynthetic characteristics of microphytobenthos in Marennes-Oléron Bay, France: preliminary results. J Exp Mar Biol Ecol 182:1-14

Blanchard G. Guarini JM (1996) Studying the role of mud temperature on the hourly variation of the photosynthetic capacity of microphytobenthos in intertidal areas. C R Acad Sci Paris Sér III 319:1153-1158

Blanchard GF, Guarini JM, Richard P, Gros Ph, Mornet F (1996) Quantifying the short-term temperature effect on light-saturated photosynthesis of intertidal microphytobenthos. Mar Ecol Prog Ser 134:309-313

Blanchard G, Guarini JM, Gros Ph, Richard P (1997) Seasonal effect on the relationship between the photosynthetic capacity of intertidal microphytobenthos and temperature. J Phycol 33:723-728

Blanchard GF, Guarini JM, Bacher C, Huet V (1998) Control of the short-term dynamics of intertidal microphytobenthos by the emersion/submersion cycle. C R Acad Sci Paris Sér III 321:501-508

Brown DH, Gibby CE, Hickman M (1972) Photosynthetic rhythms in epipelic algal populations. Br Phycol J 7:37-44

Burkholder PR, Repak A, Sibert J (1965) Studies on some Long Island Sound littoral communities of microorganisms and their primary productivity. Bull Tor Bot Club 92: $378-402$

Cadée GC, Hegeman J (1974) Primary production of the benthic microflora living on tidal flats in the Dutch Wadden Sea. Neth J Sea Res 8:260-291

Callame B, Debyser J (1954) Observations sur les mouvements des diatomées à la surface des sédiments marins de la zone intercotidale. Vie Milieu V:243-249

Cariou-Le Gall V, Blanchard GF (1995) Monthly measurements of pigment concentration from an intertidal muddy sediment of Marennes-Oléron Bay, France. Mar Ecol Prog Ser 121:171-179

Colijn F (1982) Light absorption in the waters of the Ems-Dollard Estuary and its consequences for the growth of phytoplankton and microphytobenthos. Neth J Sea Res 15: $196-216$

Colijn F, de Jonge VN (1984) Primary production of microphytobenthos in the Ems-Dollard Estuary. Mar Ecol Prog Ser 14:185-196

de Jonge VN, Colijn F (1994) Dynamics of microphytobenthos biomass in the Ems estuary. Mar Ecol Prog Ser 104: $185-196$

Droop MR (1974) The nutrient status of algal cells in continuous culture. J Mar Biol Assoc UK 54:825-855

Falkowski PG, Woodhead AD (1992) Primary productivity and biogeochemical cycles in the sea. Plenum Press, New York

Gargas E (1971) 'Sun-shade' adaptation in microbenthic algae from the Oresund. Ophelia 9:107-112

Gouleau D (1976) Le rôle des diatomées benthiques dans l'engraissement rapide des vasières atlantiques découvrantes. C R Acad Sci Paris Sér D 283:21-23

Guarini JM (1998) Modélisation de la dynamique du microphytobenthos des vasières intertidales du bassin de Marennes-Oléron. Effet des synchroniseurs physiques sur la régulation de la production. PhD thesis, Univ Paris 6 
Guarini JM, Blanchard G, Gros Ph, Harrison SJ (1997) Modelling the mud surface temperature on intertidal flats to investigate the spatio-temporal dynamics of the benthic microalgal photosynthetic capacity. Mar Ecol Prog Ser 153:25-36

Guarini JM, Blanchard G, Bacher C, Gros Ph, Riera P, Richard P, Gouleau D, Galois R, Prou J, Sauriau PG (1998) Dynamics of spatial patterns of microphytobenthic biomass: inferences from a geostatistical analysis of 2 comprehensive surveys in Marennes-Oléron Bay (France). Mar Ecol Prog Ser 166:131-141

Guarini JM, Gros Ph, Blanchard G, Bacher C (1999) Shortterm dynamics of intertidal. microphytobenthic biomass: mathematical modelling. C R Acad Sci, Paris, Life Sci 322: 363-373

Haardt H, Nielsen GAE (1980) Attenuation measurements of monochromatic light in marine sediments. Oceanol Acta 3: $333-338$

Harper MA (1977) Movements. In: Werner D (ed) The biology of diatoms. Blackwell, Oxford, p 224-249

Harrison SJ (1985) Heat exchanges in muddy intertidal sediments: Chichester Harbour, West Sussex, England. Estuar Coast Shelf Sci 20:477-490

Harrison SJ, Phizacklea AP (1987) Vertical ternperature gradients in muddy intertidal sediments in the Forth estuary, Scotland. Limnol Oceanogr 32:954-963

Hartig P, Wolfstein K, Lippemeier S, Colijn F (1998) Photosynthetic activity of natural microphytobenthos populations measured by fluorescence (PAM) and ${ }^{14} \mathrm{C}$-tracer methods; a comparison. Mar Ecol Prog Ser 166:53-62

Hay SI, Maitland TC, Paterson DM (1993) The speed of diatom migration through natural and artificial substrata. Diatom Res 8:371-384

Hopkins JT (1963) A study of the diatoms of the Ouse estuary, Sussex. I. The movement of the mud-flat diatoms in response to some chemical and physical changes. I Mar Biol Assoc UK 43:653-663

Jassby AD, Platt T (1976) Mathematical formulation of the relationship between photosynthesis and light for phytoplankton. Limnol Oceanogr 21:540-547

Jorgensen BB, Des Marais DJ (1986) A simple fiber-optic microprobe for high resolution light measurements: application in marine sediment. Limnol Oceanogr 31: $1376-1383$

Kingston MB (1999) Effect of light on vertical migration and photosynthesis of Euglena proxima (Euglenophyta). J Phycol 35:245-253

Klimant I, Meyer V, Kühl M (1995) Fiber-optic oxygen microsensors, a new tool in aquatic biology. Limnol Oceanogr 40:1159-1165

Krause-Jensen D, Sand-Jensen K (1998) Light attenuation and photosynthesis of aquatic plant communities. Limnol Oceanogr 43:396-407

Kühl M, Jorgensen BB (1992) Spectral light measurements in microbenthic phototrophic communities with a fiber-optic microprobe coupled to a sensitive diode array detector. Limnol Oceanogr 37:1813-1823

Lassen C, Ploug H, Jorgensen BB (1992) A fiber-optic scalar irradiance microsensor: application for spectral light measurements in sediments. FEMS Microbiol Ecol 86:247-254

Le Hir P, Bassoullet P, L'Yavanc J (1993) Application of a multivariate transport model for understanding cohesive sediment dynamics. In: Mehta AJ (ed) Nearshore and estuarine cohesive sediment transport. Coastal and estuarine studies. American Geophysical Union, Washington, DC, 42:467-485

Lewis MR, Smith JC (1983) A small-volume, short-incubation time method for measurement of photosynthesis as a function of incident irradiance. Mar Ecol Prog Ser 31:99-102

MacIntyre HL, Cullen JJ (1995) Fine-scale vertical resolution of chlorophyll and photosynthetic parameters in shallowwater benthos. Mar Ecol Prog Ser 122:227-237

McLusky DS (1989) The estuarine ecosystem, 2nd edn. Chapman \& Hall, New York

Meyercordt J, Meyer-Reil LA (1999) Primary production of benthic microalgae in 2 shallow coastal lagoons of different trophic status in the southern Baltic Sea. Mar Ecol Prog Ser 178:179-191

Neale PJ (1987) Algal photoinhibition and photosynthesis in the aquatic environment. In: Kyle DJ, Osmond $C B$, Arntzen CJ (eds) Photoinhibition. Elsevier Science PubIishers BV (Biomedical Division), Amsterdam, p 39-65

Palmer JD, Round FE (1965) Persistent, vertical-migration rhythms in benthic microflora. I. The effect of light and temperature on the rhythmic behaviour of Euglena obtusa. J Mar Biol Assoc UK 45:567-582

Palmer JD, Round FE (1967) Persistent, vertical-migration rhythms in benthic microflora. VI. the didal and diurnal nature of the rhythm in the diatom Hantzschia virgata. Biol Bull 132:44-55

Paterson DM (1986) The migratory behaviour of diatom assemblages in a laboratory tidal micro-ecosystem examined by low temperature scanning electron microscopy. Diatom Res 1:227-239

Paterson DM (1989) Short-term changes in the erodibility of intertidal cohesive sediments related to the migratory behavior of epipelic diatoms. Limnol Oceanogr 34: $223-234$

Paterson DM, Crawford RM (1986) The structure of benthic diatom assemblages: a preliminary account of the use and evaluation of low-temperature scanning electron microscopy. J Exp Mar Biol Ecol 95(3):279-289

Pinckney J, Zingmark RG (1991) Effects of tidal stage and sun angles on intertidal benthic microalgal productivity. Mar Ecol Prog Ser 76:81-89

Pinckney J, Zingmark RG (1993a) Biomass and production of benthic microalgal communities in estuarine habitats. Estuaries 16:887-897

Pinckney JL, Zingmark RG (1993b) Modeling the annual production of intertidal benthic microalgae in estuarine ecosystems. J Phycol 29:396-407

Rasmussen MB, Henriksen K, Jensen A (1983) Possible causes of temporal fluctuations in primary production of the microphytobenthos in the Danish Wadden Sea. Mar Biol 73:109-114

Revsbech NP, Jorgensen BB (1983) Photosynthesis of benthic microflora measured with high spatial resolution by the oxygen microprofile method: capabilities and limitations of the method. Limnol Oceanogr 28:749-756

Revsbech NP, Jargensen BB (1986) Microelectrodes: their use in microbial ecology. Adv Microb Ecol 9:273-352

Revsbech NP, Jorgensen BB, Brix BB (1981) Primary production of microalgae in sediments measured by oxygen microprofiles, $\mathrm{H}^{14} \mathrm{CO}_{3}$-fixation, and oxygen exchange methods. Limnol Oceanogr 26:717-730

Round FE (1971) Benthic marine diatoms. Oceanogr Mar Biol Annu Rev 9:83-139

Round FE (1979) Occurence and rhythmic behaviour of Tropidoneis lepidoptera in the epipelon of Barnstable Harbor, Massachusetts, USA. Mar Biol 54:215-217

Round FE, Palmer JD (1966) Persistent, vertical-migration rhythms in benthic microflora. II. Field and laboratory studies on diatoms from the banks of the river Avon. $\mathrm{J}$ Mar Biol Assoc UK 46:191-214 
Sakshaug E, Bricaud A, Dandonneau Y, Falkowski PG, Kiefer DA, Legendre L, Morel A, Parslow J, Takahashi M (1997) Parameters of photosynthesis: definitions, theory and interpretation of results. J Plankton Res 19:1637-1670

Schelske CL, Odum EP (1962) Mechanisms maintaining high productivity in Georgia estuaries. Proc Gulf Caribb Fish Inst 14:75-80

Serôdio J, da Silva JM, Catarino F (1997) Nondestructive tracing of migratory rhythms of intertidal benthic microalgae using in vivo chlorophyl a fluorescence. J Phycol 33:542-553

Editorial responsibility: Otto Kinne (Editor),

Oldendorf/Luhe, Germany
Vadeboncoeur Y, Lodge DM (1998) Dissolved inorganic carbon sources for epipelic algal production: sensitivity of primary production estimates to spatial and temporal distribution of C. Limnol Oceanogr 43:1222-1226

Wasmund N (1989) Micro-autoradiograpic determination of the viability of algae inhabiting deep sediment layers. Estuar Coast Shelf Sci 28:651-656

Wolfstein K, Hartig P (1998) The photosynthetic light dispensation system: application to microphytobenthic primary production measurements. Mar Ecol Prog Ser 166:63-71

Submitted: February 4, 1999; Accepted: August 2, 1999 Proofs received from author(s): March 6, 2000 